\section{The Efforts to Improve the Attitude of Love Culture through Karawitan Extracurricular Activities in Elementary School}

\author{
Endang Sri Maruti ${ }^{1}$, Muti Atul Maskurin ${ }^{2}$, Nanda Saputra $^{3}$ \\ 1,2Universitas PGRI Madiun, Indonesia \\ ${ }^{3}$ Sekolah Tinggi Ilmu Tarbiyah Al-Hilal Sigli, Indonesia \\ Email: endang@unipma.ac.id
}

\section{Abstract:}

This study aims to improve the attitude of love culture with Karawitan extracurricular activities to student's of SDN 01 Manisrejo, Madiun City. This study is a Classroom Action Research (CAR). The subjects of this study were all students who followed Karawitan's extracurricular strength which amounted to 24 students. Data collection techniques used were observation, questionnaires, and tests. The data analysis technique was carried out in a qualitative descriptive manner. The results show that Karawitan extracurricular activities can enhance students' cultural love attitude. In the first cycle there were only 19 students or $79.2 \%$ who could achieve indicators of cultural love attitude. Whereas in the second cycle there was an increase in the number of students who could reach 24 indicators of cultural love attitudes or $100 \%$. In addition, student activity and learning outcomes also increased. In the first cycle, $75 \%$ of the number of students had begun to be active and in the second cycle had increased to $87.5 \%$ of the number of students already active during the learning process. While for the percentage of learning outcomes in the first cycle there are $75 \%$ of the number of students who have reached the indicator and in the second cycle $91.7 \%$ of the total students have achieved the expected learning outcomes indicators.

Keywords:

extracurriculer; karawitan; love culture

\section{Introduction}

Indonesian society today are increasingly aware of the importance of character education in the child's learning process. The government also began to promote character education that was included in every subject through the 2013 Curriculum. Character education aims to strengthen and develop life values that are considered important so that a distinctive personality is formed, correcting students who behave deviating from the prevailing values at school, and build good communication with family and environment so that they can be jointly responsible for character education.

Character education is an attempt by teachers to instill or influence students to do positive things based on moral values in schools and communities so that it affects the character of the students they teach. The values of character education are derived from religion, Pancasila, culture, and objectives of national education. These values are religious, religious, tolerance, disciplinary, hard work, creative, independent, denocratic, curiosity, national spirit, love, land, water, respect for achievement, friendship, love and love, love to read, care for the environment, care for social, and responsibility. 


\section{Lakhomi Journal: Scientific Journal of Culture \\ ISSN: 2774-311X (Online), 2774-4728 (Print)}

Vol. 2, No. 4, December 2021, Page: 154-161

Email: lakhomijournal@gmail.com

In its school's application, character education is generally included in the learning of each subject. The materials related to character education should begin to be developed and linked to everyday life. This is done to implement a character education in the life of society, not only in the scope of cognitive or theory (Kurniasari, 2016). Besides putting it on eachsubject, character education can also be integrated in activities outside the classroom. There are so many ways that teachers can do to apply the character education to students. Character education can not only be taught at school but can also be taught in a family environment.

Education is one of the efforts to improve the ability of human intelligence, thus he is able to improve the quality of his life (Saleh and Mujahiddin, 2020). Education is expected to be able to answer all the challenges of the times and be able to foster national generations, so that people become reliable and of high quality, with strong characteristics, clear identities and able to deal with current and future problems (Azhar, 2018). Education and skills are the main keys in gaining social status in community life (Lubis et al, 2019).

Learning the characters on high-grade students would be require more attention than the lower grade students. Because at this stage that students begin to have an attitude of resistance to the character values. High curiosity and the desire to get recognition from the people around make students in high-grade tend to be deviant from character values. It needs a new strategy that is used to apply a character education. Students will easily achieve a learning goal when using a new and fun learning model.

In modern era such today, foreign cultures can easily enter and develop in Indonesia. Not a few of the young people who learn a foreign culture forget the culture that they have. Though Indonesian culture is one of the tools that can be used to internalize character education outside the classroom. For this reason, many elementary schools incorporate regional culture into their educational curriculum through Karawitan extracurricular activities. Aside from being a forum for student's talents and interests, Karawitan extracurricular activities can be a means of internalizing character education, especially the attitude towards regional culture. By using extracurricular Karawitan, students can learn the culture of the area as well as forming the character of students being personally noble character. In extracurricular Karawitan there are so many values that can be invested by the trainer to be carried out in the daily life of the community and in the school environment.

SDN 01 Manisrejo Madiun is one of the schools in the Madiun city that preserves Karawitan art by incorporating it into the school curriculum. Karawitan extracurricular is one of the leading extracurricular activities in SDN 01 Manisrejo, Madiun. It is not a few students who participate in extracurricular activities such Karawitan. However, in the implementation of Karawitan extracurricular trainers have not maximized in the character education, especially the character of love for regional culture. The trainer is still focused on his Karawitan without inviting students to love other regional cultures, not just Karawitan art.

Based on the description above, it can be seen that character education is needed to form the students who have noble character. The character of students, especially the attitude of love for regional culture can be improved through activities outside the face-to-face hours in class such as the extracurricular Karawitan. Therefore, the researcher conducted a class action that raised the opportunity in the form of a research entitled "The Efforts to Improve the Attitude of Love Culture through Karawitan Extracurricular Activities to Student's of SDN 01 Manisrejo". 


\section{Research Method}

This study uses a type of Classroom Action Research (CAR) by applying a descriptive qualitative approach in which the researcher describes completely and in depth about the conditions in the field. According to Supardi (2012: 105) Classroom Action Research (CAR) is an approach that makes changes towards improving the results of education and learning to improve education. This research was conducted at Elementary School of 01 Manisrejo, Madiun which has 24 students taking part in Karawitan extracurricular activities. The procedure for classroom action research is carried out in two cycles where each cycle uses the Arikunto procedure stages (2014: 16), namely planning, acting, observing, and reflecting.

Data collection techniques used in this study were interviews, observations, questionnaires, and tests. Interviews are used to determine the initial conditions of students before action is taken and determine what problems should be studied (Sugiyono, 2014: 72). Observations are used to obtain data about student's cultural love attitudes. Questionnaire is a method for collecting data in the form of polls or surveys. This questionnaire is used to measure certain variables (Suwartono, 2014: 53). Tests conducted in early research are used to measure students 'abilities or students' knowledge about the components in Karawitan.

Data analysis in this study uses models from that "we consider that analysis consensus of three current flows of activity data reduction, data display, and conclusion drawing/ verification". The first stage of this research is to reduce data, then present the data obtained, and the latter draws conclusions from existing data.

\section{Result and Discussion}

3.1 Results

Based on the research results in cycle 1, can be described in the percentage of votes indicator of success in the following table.

Table 1. The success of the action cycle 1

\begin{tabular}{lrc}
\hline \multicolumn{1}{c}{ Aspect } & Indicator & Achievement \\
\hline Student Activity & $80 \%$ & $75 \%$ \\
Increasing of culture love attitude & $80 \%$ & $79,2 \%$ \\
Learning achievement & $80 \%$ & $75 \%$ \\
\hline
\end{tabular}

The value of student activity during the musical extracurricular activities takes place in the first cycle, only $75 \%$ of students achieve completeness. While the expected student activity indicators are $80 \%$ of the number of students. In cycle 1 there were still many students who were not yet aware of the importance of maintaining and caring for gamelan instruments, and there were still many students who paid little attention to the trainer's explanation so that when they played karawitan students were still not be maximized.

Then the value of improving student's cultural love attitude in the first cycle was only $79.2 \%$ of students who achieved completeness. While the indicator of an increase in student's expected cultural love attitude is $80 \%$ of the number of students. Students do not know the musical arts so well that student's awareness in preserving musical arts. Students have not a high willingness to take part in extracurricular activities. 
For the completeness of student learning achievements in cycle 1 only $75 \%$ of students achieved completeness, while the expected success indicator was $80 \%$ of the total students. Student's knowledge of the origins of Karawitan and the components that exist in karawitan art are still very low. There are still $25 \%$ of the number of students who have not achieved mastery in improving learning achievement.

Based on the results of one cycle above, it is still necessary to study further measures to enhance the love attitude of student culture. Because the action of cycle 1 has not yet achieved completeness, it is necessary to carry out the second cycle of research actions with improvements, namely by making learning activities more interesting and adding learning videos about the development of Karawitan art abroad to increase student's insight so that students not only know about the development of music in Indonesia but also in foreign countries.

Based on the results of action in cycle 2, it can be described in the percentage of achievement of success indicators in the following table

Table 2. The success of the action cycle 2

\begin{tabular}{lcc}
\hline \multicolumn{1}{c}{ Aspect } & Indicator & Achievement \\
\hline Student activity & $80 \%$ & $87,5 \%$ \\
Increasing of culture love attitude & $80 \%$ & $100 \%$ \\
Learning achievement & $80 \%$ & $91,7 \%$ \\
\hline
\end{tabular}

The activeness value of students in cycle 2 has reached the expected completeness, which is as much as $87.5 \%$ of the total students are active when extracurricular activities take place. It is proved that the result of the action cycle 1 to cycle 2 experienced a significant increase. Students have been able to take care of the gamelan instruments well, pay attention to the coach's direction and earnestly take part in the Karawitan training.

Based on the data above, it can be concluded that through Karawitan extracurricular activities, the attitude of love for regional culture, especially Karawitan art to students of Manisrejo Elementary 01 Madiun can be improved. The value of improving the cultural love attitude of students in cycle 2 has reached $100 \%$, this result increased from cycle 1 which only $79.2 \%$ of students achieved completeness. Students have shown concern for karawitan art.

The completeness of student learning outcomes that achieve mastery in learning achievement in cycle 2 has reached $91.7 \%$ with the expected success indicator is $80 \%$ of the total students. Students have mastered the knowledge of Karawitan art history, the function of musical components, and the development of Karawitan art abroad.

From the data above, it can be concluded that the research in cycle 2 has exceeded the expected target, namely $80 \%$ of students have met the aspects according to the indicators of success. The attitude of cultural love for Manisrejo Elementary 01 Madiun has increased significantly. So the researcher feels that the action of this research is terminated until cycle 2. 


\subsection{Discussion}

The learning activities of Karawitan extracurricular at SDN 01 Manisrejo run smoothly, conducively and pleasantly. This can be proven by observation during the learning process. The data obtained from observations, namely in the first cycle of students who were active during the Karawitan extracurricular activities only $75 \%$, while in cycle 2 there were $87.5 \%$ of students who were active during extracurricular activities.

Interaction and appreciation of students in learning extracurricular activities Karawitan occurs between students to students, students with coaches, and students with regional culture. In cycle 1 only $79.2 \%$ of students cared about their friends and regional culture. While in cycle 2 , $100 \%$ of the number of students can interact well as expected.

This class action research on extracurricular Karawitan was conducted in 2 cycles. In cycle 1 , the expected indicators have not been achieved so it needs an action for cycle 2 . In cycle 2 , all indicators is increase. To find out the increase of the all success indicators from cycle 1 to cycle 2 can be seen in table 3

Table 3. The Comparison of Student's Improved Achievement

\begin{tabular}{|c|c|c|c|}
\hline Aspect & Achievement Indicators & Cycle 1 & Cycle 2 \\
\hline \multicolumn{4}{|l|}{ Student Activity } \\
\hline - The average of Student's Value & $\geq 75$ & 82 & 91,7 \\
\hline - The achievement Percentage & $80 \%$ & $75 \%$ & $87,5 \%$ \\
\hline \multicolumn{4}{|l|}{ Increasing of culture love attitude } \\
\hline - The average of Student's Value & $\geq 75$ & 80,4 & 90,8 \\
\hline - The achievement Percentage & $80 \%$ & $79,2 \%$ & $100 \%$ \\
\hline \multicolumn{4}{|l|}{ Learning achievement } \\
\hline - The average of Student's Value & $\geq 75$ & 82,5 & 92,1 \\
\hline - The achievement Percentage & $80 \%$ & $75 \%$ & $91,7 \%$ \\
\hline
\end{tabular}

To clarify the presentation of the data above, it can be seen in the improvement diagram of student achievement in figure 1

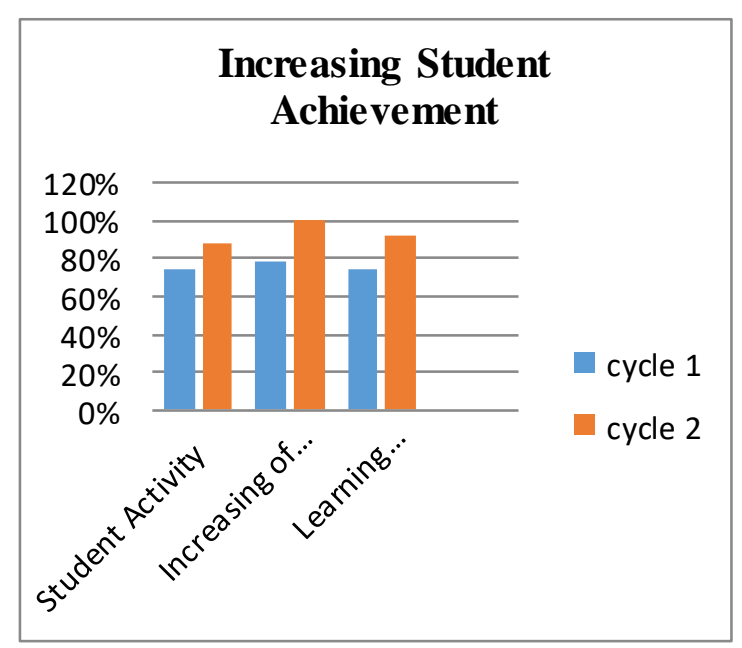

Figure 1. Diagram of Increasing Student Achievement 
Based on the data above it can be seen that there is an improvement of the student achievement in all aspects significantly. In the aspect of students' activity, the result of an increase of $12 \%$, which in cycle 1 only reached $75 \%$ of students reached the indicator and the second cycle increased to $87.5 \%$ of students who have reached the indicator. In the aspect of increasing the attitude of love culture, the results of the increase were as much as $20.8 \%$ where in cycle 1 only reached $79.2 \%$ of students who reached the indicator while in cycle 2 all the students had reached the indicator. In the aspect of student achievement, the result of an increase as much as $16.7 \%$ whereas in cycle 1 only $75 \%$ of students who can achieve the indicator, while the cycle 2 of the existing $91.7 \%$ of students who have reached the indicator. From the presentation of the data above, it is evident that the character learning outcomes of cultural love attitudes towards students can be improved through Karawitan extracurricular activities at school.

The advantages and disadvantages of Karawitan extracurricular activities in improving the attitude of cultural love for students.

a. The advantages of Karawitan extracurricular activities in improving the attitude of cultural love for students are 1) Through the fun extracurricular activities of Karawitan, students are easier to understand the history and development of Karawitan art and can easily memorize what components are in Karawitan art. By mastering deeper knowledge about Karawitan art, students can become concerned and love the arts of this region. 2) Students can master various "dolanan" songs so that they can influence student learning outcomes in the class (Javanese Language subjects), 3) Students are more aware that regional culture needs to be attracted because there are already many foreigners who study regional culture in Indonesia.

b. The disadvantages of Karawitan extracurricular activities in improving the attitude of cultural love for students are 1) In extracurricular activities Karawitan only provides knowledge and understanding about the arts, even though regional culture is very diverse. 2) The training time for extracurricular activities in Karawitan is quite long so that the process of cultivating cultural love for students requires a longer time.

There is a lack of love for culture among the younger generation. This can be seen from the level of children's interest in foreign cultures which is higher than the local culture. Such an attitude is certainly not good for children in life in their environment, because the majority of foreign cultures are inversely proportional to the culture in their area. This of course requires action from family as well as from school. Local culture needs to be preserved by the younger generations so that they are not colonized by other countries. One way that children want to love local culture is to instill an attitude of love for the wrong culture, only through extracurricular activities.

Through musical extracurricular activities, students can learn to improve. Positive values that can shape the character of students, especially the attitude of love for culture. SDN 01 Manisrejo Madiun City is one of the schools that develops musical extracurricular activities as an effort to increase the attitude of love for culture to its students. With the Karawitan extracurricular, students can get to know more about the culture of their area, then they can learn more about the arts, the Karawitan, and then a sense of love for Karawitan and other cultures and other areas will grow. After students become in love with the culture of their area, that culture can be preserved and remain the identity of the state of Indonesia. 


\section{Conclusion}

Based on the results of research on student activities and student learning outcomes in improving cultural love attitude through Karawitan extracurricular activities the following results were obtained:

1. Implementation of Karawitan extracurricular activities can improve student's cultural love attitude in accordance with the expected of the success indicators. This can be seen from the increase in student activity and student's concern for Karawitan art significantly.

2. Character learning outcomes of cultural love attitude through Karawitan extracurricular activities fulfill the determined success indicators. Significant changes occurred from cycle 1 to cycle 2 in all aspects assessed.

The advantages that exist in Karawitan extracurricular activities in enhancing student's cultural love attitude are that students enjoy the learning process because of fun activities and students are more concerned with regional arts. While the shortcomings of the Karawitan extracurricular activities in enhancing cultural love for students, namely extracurricular activities, Karawitan only focuses on the karawitan game itself, there is a lack of knowledge about various other regional cultures.

For small tables, please place it within a column and bigger table be placed in a text frame spanning to both columns. Use the Table facility available within the MSWord. The font in the row header should be bold and you can use the style available from the style palette.

\section{References}

A. K. Streit and Hadi, "Perancangan Board Game Edukasi Pendidikan Moral Dengan Menggunakan Tokoh Cerita Rakyat Nusantara Untuk Usia 13 - 15 Tahun,” J. Chem. Inf. Model., vol. 53, no. 9, pp. 1689-1699, 2018.

A. Setyawan, S. Suwandi, S. Y. Slamet, F. Keguruan, P. Universitas, and S. Maret, "Character education content in folklore pacitan's," J. Pendidik. Karakter, vol. 2, no. 119-150, pp. 199_ 211, 2017.

Azhar,A. (2018). Students' Trends in Islamic Communication Postgraduate in2010-2016 State Islamic University of North Sumatera (UINSU). Budapest International Research and Critics Institute (BIRCI-Journal), P.206-214.

D. Susanti, "Moral Education Value in Ahmad Fuadi's Novel Rantau Satu Muara," KnE Soc. Sci., pp. 237-246, 2018.

H. Munawaroh and S. H. Sri Arfiah, "Sosialisasi Nilai Cinta Tanah Air Melalui Pemutaran Film Dengan Penerapan Strategi Snowball Throwing Kombinasi Scramble Untuk Meningkatkan Pemahaman Pada Remaja Masjid Kelurahan Banyuanyar Kecamatan Banjarsari Kota Surakarta Tahun 2019." Universitas Muhammadiyah Surakarta, 2019.

I. Idawati, "Nilai-Nilai Pada Tradisi Nandong Di Desa Kampung Baru Inuman Kecamatan Inuman Kabupaten Kuantan Singingi Provinsi Riau," KOBA, vol. 3, no. 1, p. 11, 2016.

I. Kemal and R. Fitri, "Analisis Nilai Pendidikan Karakter dalam Novel diantara Asa, Cinta dan Cinta Karya Isa Elfath,” J. Metamorf., vol. 3, no. 2, pp. 45-57, 2015.

I. KURNIASARI, "Analisis Penanaman Nilai Moral Siswa Oleh Guru Pada Pembelajaran Pendidikan Pancasila Dan Kewarganegaraan Di Kelas Vii Sekolah Menengah Pertama Negeri 3 Sungai Raya Kabupaten Kubu Raya.” Ikip Pgri Pontianak, 2016.

Lubis, R., et al. (2019). Survival Strategy for Lokan Seekers in Paya Pasir Village, Kec. Marelan, Medan, Indonesia. Budapest International Research and Critics Institute-Journal (BIRCIJournal). Volume 2, No 1, Page: 293-303. 
M. B. Miles and A. M. Huberman, Qualitative data analysis: An expanded sourcebook. sage, 1994.

M. Samani and M. S. Hariyanto, "Konsep dan model pendidikan karakter," Bandung PT Remaja Rosdakarya, 2011.

N. A. Wiyani, "Format Kegiatan Kepramukaan sebagai Ekstrakurikuler Wajib di Madrasah Ibtidaiyah Dalam Kurikulum 2013," Insa. J. Pemikir. Altern. Kependidikan, vol. 19, no. 1, pp. 148-168, 2014.

Purwadi, "Pemikiran Ranggawarsita Sebagai Bahan Ajar Pendidikan Karakter," J. IKADBUDI, vol. 4, no. 10, pp. 118-130, 2016, doi: 10.21831/ikadbudi.v4i10.12026.

S. Winton, "Character education, new media, and political spectacle," J. Educ. Policy, vol. 25, no. 3, pp. 349-367, 2010.

Saleh, A., Mujahiddin. (2020). Challenges and Opportunities for Community Empowerment Practices in Indonesia during the Covid-19 Pandemic through Strengthening the Role of Higher Education. Budapest International Research and Critics Institute-Journal (BIRCIJournal). Volume 3, No 2, Page: 1105-1113 